\title{
MicroRNAs involved with hepatocellular carcinoma (Review)
}

\author{
BIJING MAO and GE WANG \\ Cancer Center, Institute of Surgical Research, Daping Hospital, Third Military Medical University, \\ Yuzhong, Chongqing 400042, P.R. China
}

Received June 4, 2015; Accepted July 13, 2015

DOI: $10.3892 / o r .2015 .4275$

\begin{abstract}
Hepatocellular carcinoma (HCC) is one of the most common malignancies, which accounts for $90 \%$ of primary liver cancer. HCC usually presents with poor outcomes due to the high rates of tumor recurrence and widespread metastasis. However, the underlying mechanism of HCC initiation and progression, which significantly hindered the development of valid approaches for early detection and treatment remain to be elucidated. As a group of small non-coding RNAs, microRNAs (miRNAs) have been demonstrated to be involved in many types of diseases especially human malignancies. Numerous miRNAs are deregulated in HCC, which may shed some light on current investigations. Since miRNAs are stable and detected easily, their ectopic expression has been reported in HCC tissues, serum/plasma and cell lines. As previously described, miRNAs serve as tumor suppressors or oncogenes, indicating that miRNAs may be useful as diagnostic, therapeutic and prognostic markers of HCC. In the present review, we assessed the latest data regarding dysregulated miRNAs in $\mathrm{HCC}$ and reviewed the reported functions of these miRNAs as they apply to the diagnosis and prognosis of HCC.
\end{abstract}

\section{Contents}

1. Introduction

2. Biogenesis of miRNAs

3. miRNAs in cancer

4. miRNAs in HCC

5. miRNAs in HCC diagnosis and prognosis

6. miRNAs in HCC treatment

Correspondence to: $\mathrm{Dr}$ Ge Wang, Cancer Center, Institute of Surgical Research, Daping Hospital, Third Military Medical University, 10 Changjiangzhilu Daping, Yuzhong, Chongqing 400042, P.R. China

E-mail: wangge70@hotmail.com

Abbreviations: HCC, hepatocellular carcinoma; miRNAs, microRNAs; 3'UTR, 3' untranslated region

Key words: hepatocellular carcinoma, miRNAs, 3'UTR, RNA-induced silencing complex, diagnosis, prognosis
7. miRNA and radiosensitivity: A new direction for HCC treatment

8. Conclusions

\section{Introduction}

Globally, hepatocellular carcinoma (HCC) is the fifth most common human cancer and the third leading cause of cancerassociated mortalities (1). In spite of the great achievements of novel therapies and diagnostic techniques, the early detection of HCC is difficult, resulting in a poor 5-year survival for $\mathrm{HCC}$ patients (ranging from 0 to 14\%) $(2,3)$. Therefore, the identification of the most specific and sensitive biomarkers for $\mathrm{HCC}$ is crucial.

MicroRNAs (miRNAs) are a large set of small non-coding RNAs, 22 nucleotides in length, that mainly bind to the seed sequences located within the 3 ' untranslated region (3'UTR) of target mRNAs. miRNAs can promote the degradation or suppress the translation of target mRNAs, eventually inhibiting the biological functions of their target genes. Different genes can be regulated by the same miRNA, while different miRNAs can be regulated by the same gene $(4,5)$. Over 2,500 human miRNAs have been found to play important roles in various physiological and pathological processes such as embryonic development, cell proliferation, differentiation, cell cycle progression, apoptosis, autophagy, angiogenesis and metabolism $(6,7)$. Recently, it has been demonstrated that miRNAs exhibit tissue- and disease-specific patterns in human cancers, indicating that miRNAs may be novel biomarkers for the early diagnosis and prognosis prediction of HCC (8). In the present review, we summarized the known alterations of miRNAs and their biological roles in the development of HCC.

\section{Biogenesis of miRNAs}

Primary miRNAs (pri-miRNAs, containing stem-loop structures) are first transcribed by RNA polymerase II and then processed into the hair-shaped precursor miRNA (pre-miRNA, 70-90 nucleotides in length) by the complex comprising RNAase III (also known as Drosha) and DGCR8/ Pasha in the nucleus (Fig. 1). Pre-miRNAs are transported into the cytoplasm by the exportin-5 complex and cleaved into mature miRNAs by Dicer (9-13). Earlier studies have identified enhancers and silencers of miRNA transcription $(11,14,15)$. Recently, other mechanisms including DNA methylation and 


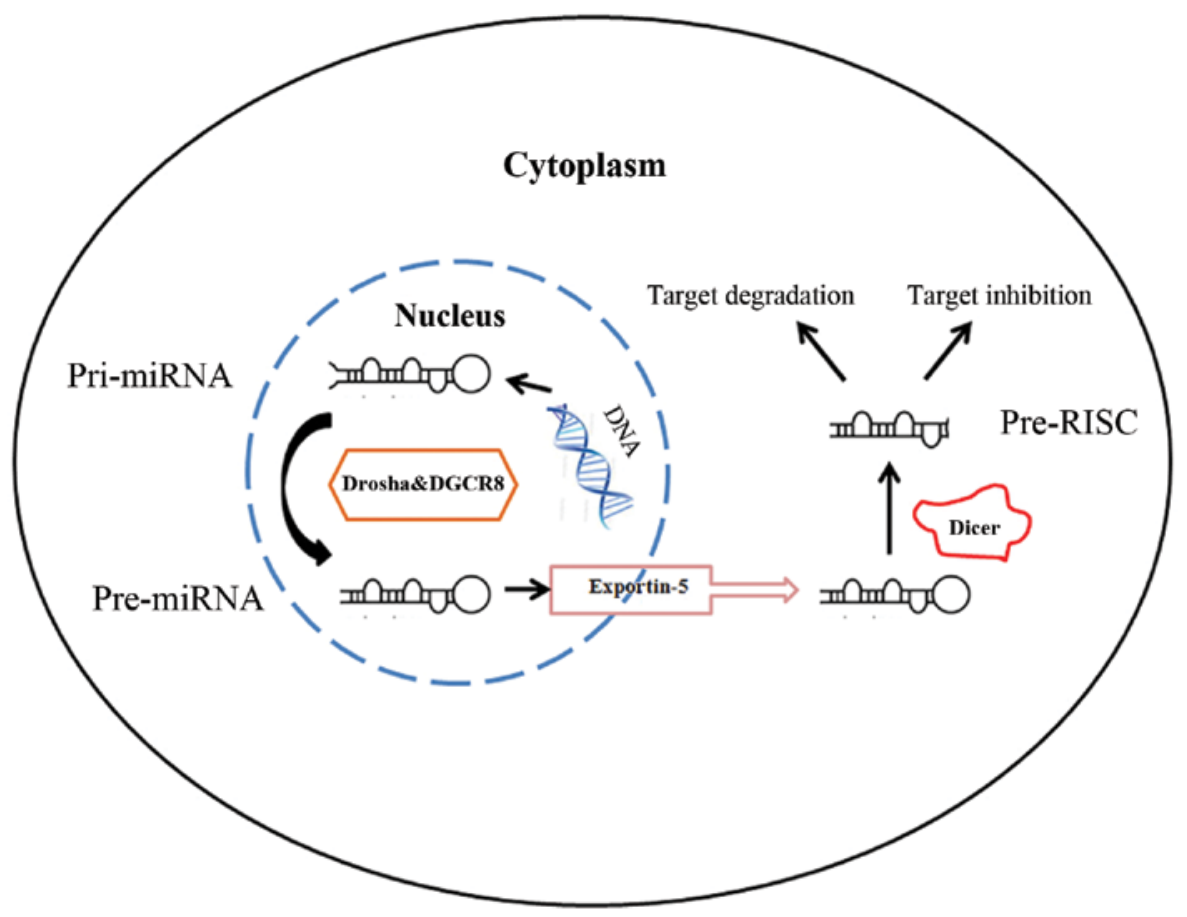

Figure 1. The biogenesis of miRNA.

histone modification have been shown to regulate the production of miRNAs $(16,17)$.

\section{3. miRNAs in cancer}

During the past decade, the multiple roles of miRNAs in the initiation and progression of human cancer have been well established. miRNAs are commonly dysregulated in tumor tissues and act as oncogenes or tumor suppressors, respectively. miRNAs are able to manipulate tumor proliferation, migration, invasion, metastasis, angiogenesis, cell cycle progression, apoptosis and autophagy. Consistently, the crucial roles of miRNAs in tumorigenesis and development have been further demonstrated in several animal models. For example, miRNA15a/miRNA-16-1 knockout mice were predisposed to develop chronic lymphocytic leukemia (18). In addition, E $\mu$-miRNA-155 transgenic mice were prone to develop a proliferative B-cell malignancy in lymph nodes (19). Collectively, these results indicated that miRNAs may be valid therapeutic targets for treating human cancers.

\section{4. miRNAs in HCC}

Numerous studies have focused on the ectopic expression (upor downregulation) of miRNAs in HCC. A panel of miRNAs have been identified to be candidate tumor suppressors or oncogene inducers and further proven to be critical factors in the regulation of malignant tumor behaviors. A brief description of these miRNAs is provided below.

Downregulation of miRNAs in HCC. The most common downregulated miRNAs in HCC are summarized in Table I. Of these miRNAs, let-7g, miR-122 and miR-199 are particularly noteworthy.
The miRNA let-7g is a member of the large let-7 family. It is significantly downregulated in human HCC tissues and is closely associated with the metastasis and poor overall survival of HCC. In vitro, restoration of let-7g markedly inhibited tumor proliferation and migration, suppressed the epithelial-mesenchymal transition (EMT), and induced cell apoptosis and cell cycle arrest by blocking the K-Ras/HMGA2/ Snail signaling pathway (20). Let-7g also targets Bcl-xL and collagen type I $\alpha 2$, thus promoting apoptosis and inhibiting migration in HCC cells.

The liver-specific miRNA-122 is significantly downregulated in a large number of HCC patients and is often inversely associated with a poor prognosis and metastasis. Restoration of miR-122 inhibits proliferation and migration, and increases apoptosis by targeting AKT3 in HCC cell lines (21). miR-122 was able to directly bind to the $3^{\prime} \mathrm{UTR}$ of the $D L X 4$ gene (Distal-less 4) and downregulate its expression, which markedly suppressed HCC cell proliferation. Considering that miR-122 is associated with tumor invasion and metastasis in HCC, Wang et al (22) performed a panel of experiments and demonstrated that miR-122 was capable of triggering the EMT, induce disruption of the cellular cytoskeleton, block the RhoA/Rock signaling pathway, enhance adhesion and suppress invasion in HCC cells. Recently, it has been suggested that cell morphology and mitochondrial functions can be markedly regulated by miR-122, proposing that miR-122 is critical for hepatocarcinogenesis (23). Thus, miR-122 knockout mice eventually developed spontaneous tumors resembling human HCC. In particular, in the Huh7, HepG2 and QSG-7701 HCC cell lines, the expression of miR-122 has been shown to be significantly inhibited by the methylation of its promoter, which was restored by treatment with the demethylation agent 5-aza-dC. Additionally, the overexpression of miR-122 induced further cell apoptosis in these HCC cells (24). 
Table I. Downregulated miRNAs in HCC.

\begin{tabular}{|c|c|c|c|}
\hline microRNA & Target genes & Characteristics & Refs. \\
\hline Let-7g & K-Ras/HMGA/Snail & Proliferation and migration & (8) \\
\hline miR-1 & ET1 & Proliferation & (9) \\
\hline miR-7 & CUL5, CCNE1 & A tumor suppressor and therapeutic application in HCC & $(59)$ \\
\hline miR-20a & Mcl-1 & Proliferation, G1 arrest and apoptosis & (10) \\
\hline miR-22 & NP & Differentiation, metastasis and prognosis of $\mathrm{HCC}$ & (39) \\
\hline $\operatorname{miR}-23 a$ & TOP1 & A potential target in regulating chemosensitivity of $\mathrm{HCC}$ & $(60)$ \\
\hline miR-26a & PIK $3 C 2 \alpha$ & $\begin{array}{l}\text { A potential therapeutic target and a new basis } \\
\text { for targeted molecular therapy of HCC }\end{array}$ & $(61)$ \\
\hline miR-26b & USP9X, TAK1, TAB3 & EMT, chemosensitivity of HCC & $(62,63)$ \\
\hline $\mathrm{miR}-27 \mathrm{a}$ & FZD7 & A promising chemosensitizing strategy for the treatment of $\mathrm{HCC}$ & $(64)$ \\
\hline $\operatorname{miR}-29 c$ & SIRT1 & A tumor suppressor in $\mathrm{HCC}$ & (40) \\
\hline miR-30a-3p & NP & Proliferation, invasion and metastasis & $(11)$ \\
\hline miR-34a & Bcl-2, c-Met & $\begin{array}{l}\text { Induces sensitivity to the antitumor effect of sorafenib in HCC, } \\
\text { a critical targeted therapy for HCC }\end{array}$ & $(65,66)$ \\
\hline miR-34b & NP & $\begin{array}{l}\text { An important component of the tumor suppressor } \\
\text { network during carcinogenesis }\end{array}$ & $(41)$ \\
\hline miR-99 & Ago2 & A potential strategy for HCC & $(67)$ \\
\hline miR-100 & plk 1 & A prognostic marker and molecular therapeutic target in $\mathrm{HCC}$ & (68) \\
\hline miR-101 & NLK & A tumor suppressor in liver cancer & $(42)$ \\
\hline miR-122 & $\begin{array}{l}\text { Cyclin G1, Bcl-w, } \\
\text { AKT3, MMP-17 }\end{array}$ & $\begin{array}{l}\text { Proliferation and apoptosis of HCC, regulation of morphology } \\
\text { and cyto-architecture of HCC, a tumor suppressor } \\
\text { and a potential therapeutic candidate }\end{array}$ & $(12-14)$ \\
\hline miR-124 & STAT3 & $\begin{array}{l}\text { A tumor suppressor and a biomarker for diagnosis and } \\
\text { therapeutics in HCC }\end{array}$ & (43) \\
\hline $\operatorname{miR}-125 b$ & eIF5A2 & Prognosis of $\mathrm{HCC}$ & $(44)$ \\
\hline $\operatorname{miR}-127$ & 7-Sep & A tumor suppressor and a potential diagnostic biomarker for $\mathrm{HCC}$ & (37) \\
\hline miR-134 & ITGB 1 & $\begin{array}{l}\text { A novel metastasis suppressor in } \mathrm{HCC} \text { and } \\
\text { a potential therapeutic target for } \mathrm{HCC}\end{array}$ & (69) \\
\hline $\operatorname{miR}-137$ & AKT2 & A valuable biomarker for $\mathrm{HCC}$ prognosis & $(45)$ \\
\hline miR-138 & CCND3 & Cell cycle & (9) \\
\hline miR-139 & TCF-4 & A therapeutic strategy for the treatment of $\mathrm{HCC}$ & $(106,107)$ \\
\hline miR-141 & $\mathrm{E} 2 \mathrm{~F} 3, \mathrm{ZEB} 2$ & $\begin{array}{l}\text { Growth and metastasis of HCC, a novel potential } \\
\text { therapeutic target for HCC treatment }\end{array}$ & $(15,16)$ \\
\hline $\operatorname{miR}-144$ & $\mathrm{E} 2 \mathrm{~F} 3$ & Proliferation and metastasis of $\mathrm{HCC}$ & (17) \\
\hline miR-145 & ADAM17, IRS1 & $\begin{array}{l}\text { A potential therapeutic and biological target for } \mathrm{HCC} \text { and a potential } \\
\text { molecular mechanism causing aberrant oncogenic signaling in HCC }\end{array}$ & $(70-73)$ \\
\hline miR-148a & DNMT1 & A tumor suppressor during $\mathrm{HCC}$ & (46) \\
\hline miR-148b & NP & An independent prognostic factor for $\mathrm{HCC}$ & (47) \\
\hline miR-185 & DNMT1 & $\begin{array}{l}\text { A potential prognostic biomarker for HCC in the early stage } \\
\text { and a novel therapeutic strategy for HCC treatment }\end{array}$ & $(48,49)$ \\
\hline miR-181a-5p & c-Met & Motility, invasion and branching morphogenesis & (18) \\
\hline miR-195 & PCMT1, Wnt3a & $\begin{array}{l}\text { Increasing tumor life span, and a potential therapeutic strategy } \\
\text { in the treatment of HCC }\end{array}$ & $(74,75)$ \\
\hline miR-199 & MMP-9 & Adhesion of $\mathrm{HCC}$ & (19) \\
\hline miR-200a & CDK6 & A potential tumor suppressor in $\mathrm{HCC}$ & (50) \\
\hline miR-202 & LRP6 & A potential tumor suppressor in $\mathrm{HCC}$ & $(51)$ \\
\hline $\operatorname{miR}-203$ & Survivin & Proliferation & (20) \\
\hline $\operatorname{miR}-212$ & RBP2 & May be important in the pathogenesis of $\mathrm{HCC}$ & $(108)$ \\
\hline $\operatorname{miR}-214$ & FGFR-1 & Potential prognostic marker and therapeutic target in HCC & $(52)$ \\
\hline miR-218 & Bmi-1, CDK6 & Proliferation and apoptosis & $(21)$ \\
\hline miR-219-5p & GPC3 & Proliferation & (9) \\
\hline miR-223 & $\mathrm{ABCB} 1$ & A therapeutic biomarker for $\mathrm{HCC}$ & (76) \\
\hline $\mathrm{miR}-302 \mathrm{~b}$ & EGFR, AKT2 & An effector in gene therapy of HCC, proliferation and growth & $(22,23)$ \\
\hline
\end{tabular}


Table I. Continued.

\begin{tabular}{|c|c|c|c|}
\hline microRNA & Target genes & Characteristics & Refs. \\
\hline $\operatorname{miR}-320$ & GNAI 1 & A new therapeutic avenue for targeting HCC metastasis & (77) \\
\hline $\operatorname{miR}-363$ & S1PR1 & A novel target for treatment of $\mathrm{HCC}$ & (78) \\
\hline miR-376a & PIK3R1 & Apoptosis, proliferation & (9) \\
\hline $\operatorname{miR}-424$ & c-Myb & $\begin{array}{l}\text { A tumor suppressor in HCC, a potential biomarker and } \\
\text { therapeutic target for HCC }\end{array}$ & (53) \\
\hline $\operatorname{miR}-425-3 p$ & NP & $\begin{array}{l}\text { Elevated expression of miR-425-3p in tumor cells is a novel marker of } \\
\text { better prognosis in HCC treated with sorafenib }\end{array}$ & (79) \\
\hline $\operatorname{miR}-433$ & CREB1 & Migration & (24) \\
\hline $\operatorname{miR}-449$ & SIRT1 & A novel targeting mechanism for $\mathrm{HCC}$ therapy & (80) \\
\hline $\operatorname{miR}-450 \mathrm{a}$ & DNMT3a & Proliferation & (25) \\
\hline miR-451 & ATF2, IKK- $\beta$ & Migration, proliferation & $(26-28)$ \\
\hline miR-491 & MMP-2/9, EMT & A new clue for preventing tumor metastasis of $\mathrm{HCC}$ & $(81)$ \\
\hline $\operatorname{miR}-503$ & $\begin{array}{l}\text { Cyclin D3, E2F3, } \\
\text { ARHGEF19 }\end{array}$ & $\begin{array}{l}\text { An important role in cell cycle regulation }(\mathrm{G} 1 / \mathrm{S}) \text { and in the } \\
\text { molecular etiology of HCC }\end{array}$ & (30) \\
\hline miR-520c-3p & GPC3 & A prospective prognosis predictor and biological treatment target of $\mathrm{HCC}$ & (54) \\
\hline miR-612 & AKT2 & An effective molecular target for HCC therapy & $(82)$ \\
\hline miR-744 & $\mathrm{c}-\mathrm{Myc}$ & Potentially useful target for miRNA-based therapies of HCC & (83) \\
\hline
\end{tabular}

miR-199a-1, miR-199a-2 and miR-199b belong to the miR-199 family. In HCC tissues, miR-199a was significantly downregulated, correlating with a higher recurrence rate and a poor prognosis. In HCC cell lines, miR-199a was able to suppress tumor proliferation and induce apoptosis and cell cycle arrest by regulating the expression of matrix metalloproteinase-9 (MMP-9), frizzled type 7 receptor (FZD7) and hypoxia-inducible factor-1 $\alpha$. In a similar manner, miR-199a-3p expression was significantly reduced in a panel of human HCC cell lines. In addition, it was shown that miR-199a-3p directly targeted CD44 and inactivated the c-Met signaling pathway. The other known targets of miR-199a-3p include the mammalian target of rapamycin (mTOR) and c-Met, which play important roles for the biological functions of miR-199a-3p as a tumor suppressor. Downregulation of miR-199a-5p was observed in more than two-thirds of HCC samples and notably associated with an advanced tumor stage. In vitro experiments suggested that miR-199a-5p directly inhibits the expression of discoidin domain receptor-1 (DDR1) and that the loss of miR-199a-5p leads to the upregulation of DDR1 and enhances the invasion of HCC cells. In another study, it was found that upregulated miR199a-5p directly inhibited the activity of E2F3 and sensitized HCC cells to routine chemotherapies (25). Of note, miR-199a-5p significantly enhanced the suppressive effects of cisplatin on cell proliferation (26), while cisplatin downregulated the level of miR-199a-5p and then induced autophagy by activating autophagy-associated gene 7, a direct target of miR-199a-5p. These controversial results remain to be clarified in the future using more powerful experimental approaches (25-34).

In addition, the marked reduction of miR-20a, miR-138, miR-503, miR-218 and miR-376a expression was detected in HCC tissues. These miRNAs have been shown to be involved in tumor proliferation, apoptosis and cell cycle regulation (35-37). Collectively, a large number of miRNAs are downregulated in human HCC and have been found to be closely associated with tumor progression and prognosis.

Upregulation of miRNAs in HCC. miRNAs can also serve as oncogenes in human cancers. In HCC, a group of onco-miRNAs (listed in Table II) has been identified, and their functions have been well defined. Of these, miR-21, miR-221 and miR-224 are the best studied. Consequently, the roles in HCC of these miRNAs are reviewed.

miR-21 is one of the most common dysregulated miRNAs in human cancers and is involved in the regulation of cell proliferation, differentiation, apoptosis, angiogenesis, migration and invasion (38-40). Recent studies have suggested that miR-21 functions as a pro-metastatic miRNA in HCC (41) and can promote the invasion and metastasis of HCC by targeting phosphatase and tensin homolog (PTEN) and heparin-degrading endosulfatase-1 (hSulf-1) and activating the AKT/ERK signaling pathways (42). The HEPN1 gene is another target of miR-21, and its silence induced by miR-21 significantly accelerated the tumor growth of HCC. In addition, mitogen-activated protein kinase-kinase 3 (MAP2K3), reversion-inducing-cysteine-rich protein with kazal motifs (RECK), and programmed cell death 4 (PDCD4) were the direct targets of miR-21, and their expression and functions were notably suppressed in HCC $(41,43,44)$.

Another overexpressed miRNA in human HCC is miR-221, and its expression is significantly correlated with a poor overall survival and recurrence-free survival. It was found that miR-221 causes rapid S-phase entry and enhances tumor growth by targeting p27, p57 and aryl hydrocarbon nuclear translocator (Arnt) in HCC. Additionally, the upregulation of miR-221 has been associated with a more aggressive phenotype of HCC and can suppress cell apoptosis by targeting the Bmf gene (45). Recently, miR-221 was shown to be able to silence 
Table II. Upregulated miRNAs in HCC.

\begin{tabular}{|c|c|c|c|}
\hline microRNA & Target genes & Characteristics & Refs. \\
\hline miR-9 & KLF17 & A predictive marker of high metastatic potential in $\mathrm{HCC}$ & (55) \\
\hline miR-10a & EphA4, CADM1 & EMT, metastasis & (9) \\
\hline miR-17-5p & p38 pathway & Multiple tumor nodules, vein invasion, shortened overall survival & (9) \\
\hline miR-18 & TNRC68 & $\begin{array}{l}\text { Proliferation and adhesion, a diagnostic and } \\
\text { prognostic marker for HCC progression }\end{array}$ & $(56)$ \\
\hline miR-21 & PTEN, RECK, PDCD4 & Migration and invasion of a stem-like population in HCC & $(31,32)$ \\
\hline $\operatorname{miR}-24$ & SOX7 & Proliferation and invasion & (109) \\
\hline miR-25 & NP & A predictive value on prognosis & $(57)$ \\
\hline miR-135a & FOXM1, MTSS1 & Metastasis & (9) \\
\hline miR-143 & FNDC3B & Metastasis & (9) \\
\hline miR-146a & NP & A potential anti-angiogenic target for HCC therapy & (84) \\
\hline miR-182 & TP53INP1 & A new target for chemotherapy of HCC & $(85)$ \\
\hline $\operatorname{miR}-184$ & INPPL1, SOX7 & As an oncogenic regulator in $\mathrm{HCC}$ & $(86,87)$ \\
\hline $\operatorname{miR}-190 b$ & IGF-1 & A therapeutic target of $\mathrm{HCC}$ & (88) \\
\hline miR-197 & CD82 & Migration and invasion & $(110)$ \\
\hline miR-210 & VMP1, AIFM3 & Metastasis, apoptosis and proliferation & (9) \\
\hline miR-216a & TSLC1 & Tumorigenesis & (9) \\
\hline miR-221 & BMF, BBC3, ANGPTL2 & $\begin{array}{l}\text { Proliferation, clonogenicity, migration/invasion, } \\
\text { G1 arrest, and apoptosis }\end{array}$ & (33) \\
\hline miR-222 & p27 & Proliferation & (111) \\
\hline $\operatorname{miR}-224$ & $\begin{array}{l}\text { PPP2R1B, NF-kB pathways, } \\
\text { Homeobox D } 10\end{array}$ & An onco-miRNA in HCC & $(34,35)$ \\
\hline miR-301a & Gax & Metastasis & (9) \\
\hline $\operatorname{miR}-373$ & PPP6C & Cell cycle & (9) \\
\hline $\operatorname{miR}-490-3 p$ & ERCIC3 & EMT & (9) \\
\hline miR-519d & $\begin{array}{l}\text { CDKN1A/p21, PTEN, } \\
\text { AKT3, TIMP2 }\end{array}$ & Proliferation, invasion and apoptosis & (9) \\
\hline $\operatorname{miR}-525-3 p$ & ZNF395 & Migration and invasion & $(112)$ \\
\hline miR-550a & CPEB4 & Metastasis & (9) \\
\hline $\operatorname{miR}-590-5 p / 3 p$ & PDCD4, PTEN & An important tumorigenic factor for $\mathrm{HCC}$ & $(58)$ \\
\hline miR-615-5p & IGF-II & Cell growth and migration & (9) \\
\hline miR-657 & TLE1, NF-кB & Proliferation & (9) \\
\hline $\operatorname{miR}-1246$ & CADM1 & Migration and invasion & (113) \\
\hline
\end{tabular}

histone deacetylase 6 (HDAC6) and enhance the malignant progression of HCC.

miR-224 is upregulated in HCC, and recent studies have shown that miR-224 can act as an onco-miRNA in HCC through activating the AKT signaling pathway (46). In a previous study, we demonstrated that miR-224 can promote migration and invasion in HCC cells by targeting the homeobox D10 (HOXD10) gene (47).

Thus, dysregulated miRNAs are frequently involved in almost every step of the initiation and progression of $\mathrm{HCC}$, indicating that these miRNAs are potential targets for the diagnosis and prognosis prediction for HCC patients.

\section{5. miRNAs in HCC diagnosis and prognosis}

Since a large number of HCC patients are diagnosed at an advanced stage of disease, the development of novel valid approaches to detect HCC earlier is crucial. Currently, $\alpha$-fetoprotein is the only marker commonly used for HCC detection in the clinic. However, its reliability is questionable and its accuracy is not satisfactory (6). Based on the amount of evidence from clinical and basic research, it has been suggested that miRNAs have potential characteristics as diagnostic markers for HCC. Technically, miRNAs in circulation and in the cytoplasm are abundant and stable enough for detection using commercial kits. For example, a recent study has shown that miR-127 is significantly downregulated in HCC and that it is a potential diagnostic biomarker for HCC (48). It has been previously demonstrated that miR-21, miR-26a, miR-27a, miR-122, miR-192, miR-223 and miR-801 can discriminate between HCC and healthy, chronic hepatitis B and cirrhosis groups (6). miR-126, miR-141 and miR-200c are also able to differentiate HCC from metastatic liver cancer with a high accuracy (49). In addition, aberrant DNA 
Table III. Circulating miRNAs as biomarkers in HCC.

\begin{tabular}{|c|c|c|c|c|}
\hline microRNAs & Sample & Clinical condition & Clinical relevance & Refs. \\
\hline miR-1 & Serum & Low level & A new independent parameter of overall survival in $\mathrm{HCC}$ & (114) \\
\hline $\begin{array}{l}\operatorname{miR}-16, \text { let-7f, } \\
\operatorname{miR}-21\end{array}$ & Serum & Low level & $\begin{array}{l}\text { The indicators to estimate the tumor size } \\
\text { or the recurrence of HCC }\end{array}$ & $(115)$ \\
\hline $\operatorname{miR}-24-3 p$ & Serum & High level in HCC & $\begin{array}{l}\text { An independent predictor of poor overall survival } \\
\text { and disease-free survival in patients with } \\
\text { hepatitis B virus-related HCC }\end{array}$ & $(116)$ \\
\hline $\operatorname{miR}-122 \mathrm{a}$ & Serum & $\begin{array}{l}\text { The level was reduced } \\
\text { in HCC }\end{array}$ & $\begin{array}{l}\text { The serum miR-122a level has } \\
\text { some value as a diagnostic tool for HCC }\end{array}$ & $(114,117)$ \\
\hline miR-139 & Plasma & Low level & A diagnostic biomarker and prognostic factor for $\mathrm{HCC}$ & (89) \\
\hline miR-143 & Serum & High level & A potential biomarker for the diagnosis of $\mathrm{HCC}$ & (118) \\
\hline miR-215 & Serum & High level & A potential biomarker for the diagnosis of $\mathrm{HCC}$ & $(118)$ \\
\hline $\operatorname{miR}-221$ & Serum & $\begin{array}{l}\text { High level in } \mathrm{HCC} \\
\text { (not statistically significant) }\end{array}$ & $\begin{array}{l}\text { May not be able to serve as a non-invasive } \\
\text { diagnostic marker for HCC }\end{array}$ & (119) \\
\hline miR-222 & Serum & High level & A useful prognostic factor for $\mathrm{HCC}$ & (120) \\
\hline
\end{tabular}

methylation of miRNA is potentially a useful parameter for the early diagnosis of $\mathrm{HCC}$, and it has been found that single locus hypermethylation of $m i R-129-2$ functions as a highly specific marker to distinguish HCC from chronic hepatitis and healthy liver tissues (50). Circulating miRNAs are also valuable for the early detection and prognosis prediction of HCC. The circulating miRNAs present in the serum and plasma of HCC patients are provided in Table III.

As previously reported, miRNAs are a powerful predictor of prognosis for cancer patients. Recently, several studies have shown the validity of miRNAs as prognostic markers in HCC (35,51-70). Upregulation of miR-9, miR-17-5p, miR-18, miR-25 and miR-590-5p/3p presented a high metastatic potential and a shorter survival in patients with HCC $(35,67-70)$. Another study has indicated that concordant DNA methylation at certain miRNA loci correlated with a poor survival for HCC patients. Therefore, methylation may be used as a biomarker to predict the prognosis for HCC patients (50). In other studies, either a single miRNA or a panel of several miRNAs was proven to be a good predictor of prognosis for HCC patients $(71,72)$.

Taken together, all of the abovementioned studies suggest that miRNAs can act as valuable biomarkers for the early diagnosis and prognosis prediction of HCC. However, controversies regarding the application of these markers in the clinic remain, thus further investigations are required.

\section{6. miRNAs in HCC treatment}

miRNAs function as tumor suppressors or oncogenes in HCC. Therefore, targeting these miRNAs may be a novel approach to treat HCC $(24,35,60,61,64,73-102)$. Currently, the therapeutic application of miRNAs mainly consists of two strategies: miRNA inhibition and miRNA replacement.

miRNA inhibition. The aim of miRNA inhibition is to suppress oncogenic miRNAs using miRNA antagonists that usually involve some chemical changes to heighten binding, reduce nuclease resistance and promote cellular intake (6). Evidence has suggested that miR-146a, miR-182, miR-184, and miR$190 \mathrm{~b}$ can act as therapeutic targets for HCC (98-102).

miRNA replacement. The aim of miRNA replacement is to restore the level of tumor suppressor miRNAs. In HCC cell lines, restoration of $\mathrm{miR}-26 \mathrm{a} / \mathrm{b}$ was able to increase their chemosensitivity, which was favorable for the targeted molecular therapy of HCC (75-77). A previous study has shown that miR-26a replacement using an adeno-associated (AAV8) delivery system decreased the tumorigenicity in a mouse model of HCC (49). Another example is that miR-122 can be used as a tumor suppressor through AAV-mediated delivery in a mouse model of HCC (49). Of these miRNAs, miR-34a is particularly noteworthy as it is the first miRNA mimic to reach the clinic (49) and is capable of inducing sensitivity to the antitumor effect of sorafenib in the treatment of $\operatorname{HCC}(79,80)$. Furthermore, miR-425-3p is a promising prognostic marker in HCC treated with sorafenib (93).

The therapeutic application of miRNAs is a promising strategy for HCC treatment. However, it is well known that one miRNA regulates multiple target genes and that artificially up- or downregulating the level of miRNAs may result in undesirable off-target effects. Thus, the application of miRNAs for HCC treatment remains to be examined in clinical trials.

\section{7. miRNA and radiosensitivity: A new direction for HCC treatment}

The rapid development of radiation techniques has led to radiotherapy becoming a major treatment for HCC. However, a subgroup of HCC patients present intrinsic or acquired resistance to routine radiotherapy, which significantly hinders the therapeutic effects and patient outcomes. Therefore, determining methods to improve the effects of radiotherapy is of interest to oncologists and radiologists. Recent findings have shown that miRNAs are closely associated with radiotherapy outcomes and are involved in radiosensitivity (103). Some miRNAs can act as biomarkers to predict the cellular sensitivities to radiotherapy, while others enhance or reduce 
radiosensitivity in vitro and in vivo. For example, miRNA-381 promoted the radiosensitivity of esophageal squamous cell carcinoma (ESCC), and its expression played a vital role in the radiosensitivity of ESCC (104). In addition, miRNA-25 is overexpressed in radio-resistant non-small cell lung cancer (NSCLC) patients, and miRNA-25 affected radiosensitivity by regulating BTG2 directly in NSCLC cells. Overexpression of miRNA-145 promoted the radiosensitivity of cervical cancer and is a potential new biomarker of radio-sensitizing treatment for cervical cancer (105). Based on the abovementioned data, miRNAs play a crucial role in radiosensitivity for cancer. However, the relationship between miRNAs and HCC radiosensitivity has yet to be reported. Therefore, in view of the importance of miRNAs on radiosensitivity, their mechanisms in HCC should be elucidated.

\section{Conclusions}

In summary, miRNAs are widely used in many areas of cancer, especially in HCC, including the early diagnosis, prognosis prediction, follow-up monitoring and target therapies. Undoubtedly, miRNAs have important effects on HCC; therefore, miRNA-based therapies pose a significant challenge for HCC treatment. However, investigations regarding miRNAs cannot yet be applied in the clinic. Thus, more well-designed studies are required to focus on their translational values in the future. The accuracy of miRNA detection needs to be further improved to avoid variations in the technical procedures. Additionally, more large randomized prospective clinical trials are required for the application of miRNAs to assess their potential efficacy in HCC treatment, especially for the radiotherapy of $\mathrm{HCC}$.

\section{Acknowledgements}

The present review was supported by the National Natural Science Foundation of China (grant nos. 81272498, 30973457 and 30901764).

\section{References}

1. Forner A, Llovet JM and Bruix J: Hepatocellular carcinoma. Lancet 379: 1245-1255, 2012.

2. Schwartz M, Roayaie S and Konstadoulakis M: Strategies for the management of hepatocellular carcinoma. Nat Clin Pract Oncol 4: 424-432, 2007.

3. Poon RT and Fan ST: Hepatectomy for hepatocellular carcinoma: Patient selection and postoperative outcome. Liver Transpl 10 (2 Suppl 1): S39-S45, 2004.

4. He L and Hannon GJ: MicroRNAs: Small RNAs with a big role in gene regulation. Nat Rev Genet 5: 522-531, 2004.

5. Kloosterman WP and Plasterk RH: The diverse functions of microRNAs in animal development and disease. Dev Cell 11: 441-450, 2006

6. D'Anzeo M, Faloppi L, Scartozzi M, Giampieri R, Bianconi M, Del Prete M, Silvestris N and Cascinu S: The role of microRNAs in hepatocellular carcinoma: From molecular biology to treatment. Molecules 19: 6393-6406, 2014.

7. Carthew RW and Sontheimer EJ: Origins and mechanisms of miRNAs and siRNAs. Cell 136: 642-655, 2009.

8. Garajová I, Le Large TY, Frampton AE, Rolfo C, Voortman J and Giovannetti E: Molecular mechanisms underlying the role of microRNAs in the chemoresistance of pancreatic cancer. Biomed Res Int 2014: 678401, 2014.

9. Ambros V: The functions of animal microRNAs. Nature 431: $350-355,2004$
10. Han J, Lee Y, Yeom KH, Kim YK, Jin H and Kim VN: The Drosha-DGCR8 complex in primary microRNA processing. Genes Dev 18: 3016-3027, 2004.

11. Lee Y, Ahn C, Han J, Choi H, Kim J, Yim J, Lee J, Provost P, Rådmark O, Kim S, et al: The nuclear RNase III Drosha initiates microRNA processing. Nature 425: 415-419, 2003.

12. Yi R, Qin Y, Macara IG and Cullen BR: Exportin-5 mediates the nuclear export of pre-microRNAs and short hairpin RNAs. Genes Dev 17: 3011-3016, 2003.

13. Denli AM, Tops BB, Plasterk RH, Ketting RF and Hannon GJ: Processing of primary microRNAs by the microprocessor complex. Nature 432: 231-235, 2004.

14. Borchert GM, Lanier W and Davidson BL: RNA polymerase III transcribes human microRNAs. Nat Struct Mol Biol 13: 1097-1101, 2006.

15. Cai $\mathrm{X}$, Hagedorn $\mathrm{CH}$ and Cullen BR: Human microRNAs are processed from capped, polyadenylated transcripts that can also function as mRNAs. RNA 10: 1957-1966, 2004.

16. Weber B, Stresemann C, Brueckner B and Lyko F: Methylation of human microRNA genes in normal and neoplastic cells. Cell Cycle 6: 1001-1005, 2007.

17. Scott GK, Mattie MD, Berger CE, Benz SC and Benz CC: Rapid alteration of microRNA levels by histone deacetylase inhibition. Cancer Res 66: 1277-1281, 2006.

18. Klein U, Lia M, Crespo M, Siegel R, Shen Q, Mo T, AmbesiImpiombato A, Califano A, Migliazza A, Bhagat G, et al: The DLEU2/miR-15a/16-1 cluster controls B cell proliferation and its deletion leads to chronic lymphocytic leukemia. Cancer Cell 17: 28-40, 2010.

19. Costinean S, Zanesi N, Pekarsky Y, Tili E, Volinia S, Heerema N and Croce CM: Pre-B cell proliferation and lymphoblastic leukemia/high-grade lymphoma in E(mu)-miR155 transgenic mice. Proc Natl Acad Sci USA 103: 7024-7029, 2006.

20. Chen KJ, Hou Y, Wang K, Li J, Xia Y, Yang XY, Lv G, Xing XL and Shen F: Reexpression of Let-7g microRNA inhibits the proliferation and migration via K-Ras/HMGA2/snail axis in hepatocellular carcinoma. Biomed Res Int 2014: 742417, 2014.

21. Nassirpour R, Mehta PP and Yin MJ: miR-122 regulates tumorigenesis in hepatocellular carcinoma by targeting AKT3. PLoS One 8: e79655, 2013

22. Wang SC, Lin XL, Li J, Zhang TT, Wang HY, Shi JW, Yang S, Zhao WT, Xie RY, Wei F, et al: MicroRNA-122 triggers mesenchymal-epithelial transition and suppresses hepatocellular carcinoma cell motility and invasion by targeting RhoA. PLoS One 9: e101330, 2014.

23. Jin JC, Zhang X, Jin XL, Qian CS, Jiang H and Ruan Y: MicroRNA-122 regulation of the morphology and cytoarchitecture of hepatoma carcinoma cells. Mol Med Rep 9: 1376-1380, 2014.

24. Xing TJ, Xu HT, Yu WQ and Jiang DF: Methylation regulation of liver-specific microRNA-122 expression and its effects on the proliferation and apoptosis of hepatocellular carcinoma cells. Genet Mol Res 12: 3588-3597, 2013.

25. Lee JM, Heo MJ, Lee CG, Yang YM and Kim SG: Increase of miR-199a-5p by protoporphyrin IX, a photocatalyzer, directly inhibits E2F3, sensitizing mesenchymal tumor cells to anticancer agents. Oncotarget 6: 3918-3931, 2015.

26. Xu N, Zhang J, Shen C, Luo Y, Xia L, Xue F and Xia Q: Cisplatin-induced downregulation of miR-199a-5p increases drug resistance by activating autophagy in HCC cell. Biochem Biophys Res Commun 423: 826-831, 2012.

27. Peveling-Oberhag J, Seiz A, Döring C, Hartmann S, Köberle V, Liese J, Zeuzem S, Hansmann ML and Piiper A: MicroRNA profiling of laser-microdissected hepatocellular carcinoma reveals an oncogenic phenotype of the tumor capsule. Transl Oncol 7: 672-680, 2014.

28. Wang CX, Song W, Li ZJ, Song B, Wu DH, Sun AM and Chen LH: MicroRNA profiling in patients with hepatocellular carcinoma. Nan Fang Yi Ke Da Xue Xue Bao 30: 976-977, 2010 (In Chinese)

29. Zhang J, Zhang D, Wu GQ, Feng ZY and Zhu SM: Propofol inhibits the adhesion of hepatocellular carcinoma cells by upregulating microRNA-199a and downregulating MMP-9 expression. Hepatobiliary Pancreat Dis Int 12: 305-309, 2013.

30. Fornari F, Milazzo M, Chieco P, Negrini M, Calin GA, Grazi GL, Pollutri D, Croce CM, Bolondi L and Gramantieri L: MiR-199a-3p regulates mTOR and c-Met to influence the doxorubicin sensitivity of human hepatocarcinoma cells. Cancer Res 70: 5184-5193, 2010. 
31. Henry JC, Park JK, Jiang J, Kim JH, Nagorney DM, Roberts LR, Banerjee S and Schmittgen TD: miR-199a-3p targets CD44 and reduces proliferation of CD44 positive hepatocellular carcinoma cell lines. Biochem Biophys Res Commun 403: 120-125, 2010.

32. Jia XQ, Cheng HQ, Qian X, Bian CX, Shi ZM, Zhang JP Jiang BH and Feng ZQ: Lentivirus-mediated overexpression of microRNA-199a inhibits cell proliferation of human hepatocellular carcinoma. Cell Biochem Biophys 62: 237-244, 2012.

33. Shen Q, Cicinnati VR, Zhang X, Iacob S, Weber F, Sotiropoulos GC, Radtke A, Lu M, Paul A, Gerken G, et al: Role of microRNA-199a-5p and discoidin domain receptor 1 in human hepatocellular carcinoma invasion. Mol Cancer 9: 227, 2010

34. Song J, Gao L, Yang G, Tang S, Xie H, Wang Y, Wang J, Zhang Y, Jin J, Gou Y, et al: MiR-199a regulates cell proliferation and survival by targeting FZD7. PLoS One 9: e110074, 2014.

35. Otsuka M, Kishikawa T, Yoshikawa T, Ohno M, Takata A, Shibata $\mathrm{C}$ and Koike K: The role of microRNAs in hepatocarcinogenesis: Current knowledge and future prospects. J Gastroenterol 49: 173-184, 2014.

36. Fan MQ, Huang CB, Gu Y, Xiao Y, Sheng JX and Zhong L: Decrease expression of microRNA-20a promotes cancer cell proliferation and predicts poor survival of hepatocellular carcinoma. J Exp Clin Cancer Res 32: 21, 2013.

37. Xiao F, Zhang W, Chen L, Chen F, Xie H, Xing C, Yu X, Ding S, Chen K, Guo H, et al: MicroRNA-503 inhibits the G1/S transition by downregulating cyclin D3 and E2F3 in hepatocellular carcinoma. J Transl Med 11: 195, 2013.

38. Chen J and Wang X: MicroRNA-21 in breast cancer: Diagnostic and prognostic potential. Clin Transl Oncol 16: 225-233, 2014.

39. Huang Y, Yang YB, Zhang XH, Yu XL, Wang ZB and Cheng XC: MicroRNA-21 gene and cancer. Med Oncol 30: 376, 2013.

40. Pan X, Wang ZX and Wang R: MicroRNA-21: A novel therapeutic target in human cancer. Cancer Biol Ther 10: 1224-1232, 2010.

41. Zhou L, Yang ZX, Song WJ, Li QJ, Yang F, Wang DS, Zhang N and Dou KF: MicroRNA-21 regulates the migration and invasion of a stem-like population in hepatocellular carcinoma. Int J Oncol 43: 661-669, 2013.

42. Bao L, Yan Y, Xu C, Ji W, Shen S, Xu G, Zeng Y, Sun B, Qian H, Chen L, et al: MicroRNA-21 suppresses PTEN and hSulf-1 expression and promotes hepatocellular carcinoma progression through AKT/ERK pathways. Cancer Lett 337: 226-236, 2013.

43. Hu S, Tao R, Wang S, Wang C, Zhao X, Zhao H, Li L, Zhu S, He Y, Jiang X, et al: MicroRNA-21 promotes cell proliferation in human hepatocellular carcinoma partly by targeting HEPN1. Tumour Biol: Feb 17, 2015 (Epub ahead of print).

44. Xu G, Zhang Y, Wei J, Jia W, Ge Z, Zhang Z and Liu X: MicroRNA-21 promotes hepatocellular carcinoma HepG2 cell proliferation through repression of mitogen-activated protein kinase-kinase 3. BMC Cancer 13: 469, 2013.

45. Gramantieri L, Fornari F, Ferracin M, Veronese A, Sabbioni S, Calin GA, Grazi GL, Croce CM, Bolondi L and Negrini M: MicroR NA-221 targets Bmf in hepatocellular carcinoma and correlates with tumor multifocality. Clin Cancer Res 15 5073-5081, 2009.

46. Ma D, Tao X, Gao F, Fan C and Wu D: miR-224 functions as an onco-miRNA in hepatocellular carcinoma cells by activating AKT signaling. Oncol Lett 4: 483-488, 2012.

47. Li Q, Ding C, Chen C, Zhang Z, Xiao H, Xie F, Lei L, Chen Y, Mao B, Jiang M, et al: miR-224 promotion of cell migration and invasion by targeting Homeobox D 10 gene in human hepatocellular carcinoma. J Gastroenterol Hepatol 29: 835-842, 2014.

48. Zhou J, Lu S, Yang S, Chen H, Shi H, Miao M and Jiao B MicroRNA-127 post-transcriptionally downregulates Sept7 and suppresses cell growth in hepatocellular carcinoma cells. Cell Physiol Biochem 33: 1537-1546, 2014.

49. Callegari E, Elamin BK, Sabbioni S, Gramantieri L and Negrini M: Role of microRNAs in hepatocellular carcinoma: A clinical perspective. Onco Targets Ther 6: 1167-1178, 2013.

50. Anwar SL and Lehmann U: DNA methylation, microRNAs, and their crosstalk as potential biomarkers in hepatocellular carcinoma. World J Gastroenterol 20: 7894-7913, 2014.

51. Zhou L, He J and Zhang Y: MicroRNA-22 expression in hepatocellular carcinoma and its correlation with ezrin protein. J Int Med Res 41: 1009-1016, 2013.

52. Bae HJ, Noh JH, Kim JK, Eun JW, Jung KH, Kim MG, Chang YG, Shen Q, Kim SJ, Park WS, et al: MicroRNA-29c functions as a tumor suppressor by direct targeting oncogenic SIRT1 in hepatocellular carcinoma. Oncogene 33: 2557-2567, 2014.
53. Xie K, Liu J, Chen J, Dong J, Ma H, Liu Y and Hu Z: Methylationassociated silencing of microRNA-34b in hepatocellular carcinoma cancer. Gene 543: 101-107, 2014.

54. Shen Q, Bae HJ, Eun JW, Kim HS, Park SJ, Shin WC, Lee EK, Park S, Park WS, Lee JY, et al: MiR-101 functions as a tumor suppressor by directly targeting nemo-like kinase in liver cancer. Cancer Lett 344: 204-211, 2014.

55. Lu Y, Yue X, Cui Y, Zhang J and Wang K: MicroRNA-124 suppresses growth of human hepatocellular carcinoma by targeting STAT3. Biochem Biophys Res Commun 441: 873-879, 2013.

56. Tsang FH, Au V, Lu WJ, Shek FH, Liu AM, Luk JM, Fan ST, Poon RT and Lee NP: Prognostic marker microRNA-125b inhibits tumorigenic properties of hepatocellular carcinoma cells via suppressing tumorigenic molecule eIF5A2. Dig Dis Sci 59: 2477-2487, 2014.

57. Liu LL, Lu SX, Li M, Li LZ, Fu J, Hu W, Yang YZ, Luo RZ, Zhang CZ, Yun JP: FoxD3-regulated microRNA-137 suppresses tumour growth and metastasis in human hepatocellular carcinoma by targeting AKT2. Oncotarget 5: 5113-5124, 2014.

58. Long XR, He Y,Huang C and Li J: MicroRNA-148a is silenced by hypermethylation and interacts with DNA methyltransferase 1 in hepatocellular carcinogenesis. Int J Oncol 44: 1915-1922, 2014.

59. Zhang Z, Zheng W and Hai J: MicroRNA-148b expression is decreased in hepatocellular carcinoma and associated with prognosis. Med Oncol 31: 984, 2014

60. Zhi Q, Zhu J, Guo X, He S, Xue X, Zhou J, Hu B, Li H, Chen S, Zhao $\mathrm{H}$, et al: MMetastasis-related miR-185 is a potential prognostic biomarker for hepatocellular carcinoma in early stage. Biomed Pharmacother 67: 393-398, 2013.

61. Qadir XV, Han C, Lu D, Zhang J and Wu T: miR-185 inhibits hepatocellular carcinoma growth by targeting the DNMT1/ PTEN/Akt pathway. Am J Pathol 184: 2355-2364, 2014.

62. Xiao F, Zhang W, Zhou L, Xie H, Xing C, Ding S, Chen K and Zheng S: microRNA-200a is an independent prognostic factor of hepatocellular carcinoma and induces cell cycle arrest by targeting CDK6. Oncol Rep 30: 2203-2210, 2013.

63. Zhang Y, Zheng D, Xiong Y, Xue C, Chen G, Yan B and Ye Q: miR-202 suppresses cell proliferation in human hepatocellular carcinoma by downregulating LRP6 post-transcriptionally. FEBS Lett 588: 1913-1920, 2014

64. Wang J, Li J, Wang X, Zheng C and Ma W: Downregulation of microRNA-214 and overexpression of FGFR-1 contribute to hepatocellular carcinoma metastasis. Biochem Biophys Res Commun 439: 47-53, 2013.

65. Yu L, Ding GF, He C, Sun L, Jiang Y and Zhu L: MicroRNA-424 is down-regulated in hepatocellular carcinoma and suppresses cell migration and invasion through c-Myb. PLoS One 9: e91661, 2014.

66. Miao HL, Lei CJ, Qiu ZD, Liu ZK, Li R, Bao ST and Li MY: MicroRNA-520c-3p inhibits hepatocellular carcinoma cell proliferation and invasion through induction of cell apoptosis by targeting glypican-3. Hepatol Res 44: 338-348, 2014.

67. Sun Z, Han Q, Zhou N, Wang S, Lu S, Bai C and Zhao RC: MicroRNA-9 enhances migration and invasion through KLF17 in hepatocellular carcinoma. Mol Oncol 7: 884-894, 2013.

68. Murakami Y, Tamori A, Itami S, Tanahashi T, Toyoda $\mathrm{H}$, Tanaka M, Wu W, Brojigin N, Kaneoka Y, Maeda A, et al: The expression level of miR-18b in hepatocellular carcinoma is associated with the grade of malignancy and prognosis. BMC Cancer 13: 99, 2013.

69. Su ZX, Zhao J, Rong ZH, Geng WM, Wu YG and Qin CK: Upregulation of microRNA-25 associates with prognosis in hepatocellular carcinoma. Diagn Pathol 9: 47, 2014.

70. Yang H, Zheng W,Zhao W, Guan C and An J: Roles of miR-590-5p and miR-590-3p in the development of hepatocellular carcinoma. Nan Fang Yi Ke Da Xue Xue Bao 33: 804-811, 2013 (In Chinese).

71. Jiang L, Cheng Q, Zhang BH and Zhang MZ: Circulating microRNAs as biomarkers in hepatocellular carcinoma screening: A validation set from China. Medicine 94: e603, 2015.

72. Wen Y, Han J, Chen J, Dong J, Xia Y, Liu J, Jiang Y, Dai J, Lu J, Jin G, et al: Plasma miRNAs as early biomarkers for detecting hepatocellular carcinoma. Int J Cancer 37: 1679-1690, 2015.

73. Zhang X, Hu S, Zhang X, Wang L, Zhang X, Yan B, Zhao J, Yang A and Zhang R: MicroRNA-7 arrests cell cycle in G1 phase by directly targeting CCNE1 in human hepatocellular carcinoma cells. Biochem Biophys Res Commun 443: 1078-1084, 2014.

74. Wang N, Zhu M, Tsao SW, Man K, Zhang Z and Feng Y: MiR-23a-mediated inhibition of topoisomerase 1 expression potentiates cell response to etoposide in human hepatocellular carcinoma. Mol Cancer 12: 119, 2013. 
75. Chai ZT, Kong J, Zhu XD, Zhang YY, Lu L, Zhou JM, Wang LR, Zhang KZ, Zhang QB, Ao JY, et al: MicroRNA-26a inhibits angiogenesis by down-regulating VEGFA through the PIK3C $2 \alpha / \mathrm{Akt} / \mathrm{HIF}-1 \alpha$ pathway in hepatocellular carcinoma. PLoS One 8: e77957, 2013.

76. Shen G, Lin Y, Yang X, Zhang J, Xu Z and Jia H: MicroRNA-26b inhibits epithelial-mesenchymal transition in hepatocellular carcinoma by targeting USP9X. BMC Cancer 14: 393, 2014.

77. Zhao N, Wang R, Zhou L, Zhu Y, Gong J and Zhuang SM: MicroRNA-26b suppresses the NF- $\kappa$ B signaling and enhances the chemosensitivity of hepatocellular carcinoma cells by targeting TAK1 and TAB3. Mol Cancer 13: 35, 2014.

78. Chen Z, Ma T, Huang C, Zhang L, Lv X, Xu T, Hu T and Li J: MiR-27a modulates the MDR1/P-glycoprotein expression by inhibiting FZD7/ $\beta$-catenin pathway in hepatocellular carcinoma cells. Cell Signal 25: 2693-2701, 2013.

79. Yang F, Li QJ, Gong ZB, Zhou L, You N, Wang S, Li XL, Li JJ, An JZ, Wang DS, et al: MicroRNA-34a targets Bcl-2 and sensitizes human hepatocellular carcinoma cells to sorafenib treatment. Technol Cancer Res Treat 13: 77-86, 2014.

80. Dang Y, Luo D, Rong M and Chen G: Underexpression of miR-34a in hepatocellular carcinoma and its contribution towards enhancement of proliferating inhibitory effects of agents targeting c-MET. PLoS One 8: e61054, 2013.

81. Zhang J, Jin H, Liu H, Lv S, Wang B, Wang R, Liu H, Ding M, Yang Y, Li L, et al: MiRNA-99a directly regulates AGO2 through translational repression in hepatocellular carcinoma. Oncogenesis 3: e97, 2014

82. Chen P, Zhao X and Ma L: Downregulation of microRNA-100 correlates with tumor progression and poor prognosis in hepatocellular carcinoma. Mol Cell Biochem 383: 49-58, 2013.

83. Zha R, Guo W, Zhang Z, Qiu Z, Wang Q, Ding J, Huang S, Chen T, Gu J, Yao M, et al: Genome-wide screening identified that miR-134 acts as a metastasis suppressor by targeting integrin $\beta 1$ in hepatocellular carcinoma. PLoS One 9: e87665, 2014.

84. Duan X, Hu J, Wang Y, Gao J, Peng D and Xia L: MicroRNA-145: A promising biomarker for hepatocellular carcinoma (HCC). Gene 541: 67-68, 2014.

85. Liu Y, Wu C, Wang Y, Wen S, Wang J, Chen Z, He Q and Feng D MicroRNA-145 inhibits cell proliferation by directly targeting ADAM17 in hepatocellular carcinoma. Oncol Rep 32: 1923-1930, 2014.

86. Wang Y, Hu C, Cheng J, Chen B, Ke Q, Lv Z, Wu J and Zhou Y: MicroRNA-145 suppresses hepatocellular carcinoma by targeting IRS1 and its downstream Akt signaling. Biochem Biophys Res Commun 446: 1255-1260, 2014

87. Noh JH, Chang YG, Kim MG, Jung KH, Kim JK, Bae HJ, Eun JW, Shen Q, Kim SJ, Kwon SH, et al: MiR-145 functions as a tumor suppressor by directly targeting histone deacetylase 2 in liver cancer. Cancer Lett 335: 455-462, 2013.

88. Amer M, Elhefnawi M, El-Ahwany E, Awad AF, Gawad NA Zada S and Tawab FM: Hsa-miR-195 targets PCMT1 in hepatocellular carcinoma that increases tumor life span. Tumour Biol 35: 11301-11309, 2014

89. Yang Y, Li M, Chang S, Wang L, Song T, Gao L, Hu L, Li Z, Liu L, Yao J, et al: MicroRNA-195 acts as a tumor suppressor by directly targeting Wnt3a in HepG2 hepatocellular carcinoma cells. Mol Med Rep 10: 2643-2648, 2014.

90. Yang T, Zheng ZM, Li XN, Li ZF, Wang Y, Geng YF, Bai L and Zhang XB: MiR-223 modulates multidrug resistance via downregulation of ABCB1 in hepatocellular carcinoma cells. Exp Bio Med 238: 1024-1032, 2013.

91. Yao J, Liang LH, Zhang Y, Ding J, Tian Q, Li JJ and He XH: GNAI1 suppresses tumor cell migration and invasion and is posttranscriptionally regulated by $\mathrm{mir}-320 \mathrm{a} / \mathrm{c} / \mathrm{d}$ in hepatocellular carcinoma. Cancer Biol Med 9: 234-241, 2012.

92.Zhou P, Huang G, Zhao Y, Zhong D, Xu Z, Zeng Y, Zhang Y, Li S and He F: MicroRNA-363-mediated downregulation of S1PR1 suppresses the proliferation of hepatocellular carcinoma cells. Cell Signal 26: 1347-1354, 2014.

93. Vaira V, Roncalli M, Carnaghi C, Faversani A, Maggioni M, Augello C, Rimassa L, Pressiani T, Spagnuolo G, Di Tommaso L et al: MicroRNA-425-3p predicts response to sorafenib therapy in patients with hepatocellular carcinoma. Liver Int 35: 1077-1086, 2015.

94.Zhang H, Feng Z, Huang R, Xia Z, Xiang G and Zhang J: MicroRNA-449 suppresses proliferation of hepatoma cell lines through blockade lipid metabolic pathway related to SIRT1. Int J Oncol 45: 2143-2152, 2014
95. Zhou Y, Li Y, Ye J, Jiang R, Yan H, Yang X, Liu Q and Zhang J: MicroRNA-491 is involved in metastasis of hepatocellular carcinoma by inhibitions of matrix metalloproteinase and epithelial to mesenchymal transition. Liver Int 33: 1271-1280, 2013.

96. Tang J, Tao ZH, Wen D, Wan JL, Liu DL, Zhang S, Cui JF, Sun HC, Wang L, Zhou J, et al: MiR-612 suppresses the stemness of liver cancer via Wnt $/ \beta$-catenin signaling. Biochem Biophys Res Commun 447: 210-215, 2014.

97. Lin F, Ding R, Zheng S, Xing D, Hong W, Zhou Z and Shen J: Decrease expression of microRNA-744 promotes cell proliferation by targeting c-Myc in human hepatocellular carcinoma. Cancer Cell Int 14: 58, 2014.

98. Zhu K, Pan Q, Zhang X, Kong LQ, Fan J, Dai Z, Wang L, Yang XR, Hu J, Wan JL, et al: MiR-146a enhances angiogenic activity of endothelial cells in hepatocellular carcinoma by promoting PDGFRA expression. Carcinogenesis 34: 2071-2079, 2013.

99. Qin J, Luo M, Qian H and Chen W: Upregulated miR-182 increases drug resistance in cisplatin-treated HCC cell by regulating TP53INP1. Gene 538: 342-347, 2014.

100. Gao B, Gao K, Li L, Huang Z and Lin L: miR-184 functions as an oncogenic regulator in hepatocellular carcinoma (HCC). Biomed Pharmacother 68: 143-148, 2014

101. Wu GG, Li WH, He WG, Jiang N, Zhang GX, Chen W, Yang HF, Liu QL, Huang YN, Zhang L, et al: Mir-184 post-transcriptionally regulates SOX7 expression and promotes cell proliferation in human hepatocellular carcinoma. PLoS One 9: e88796, 2014.

102. Hung TM, Ho CM, Liu YC, Lee JL, Liao YR, Wu YM, Ho MC, Chen CH, Lai HS and Lee PH: Up-regulation of microRNA-190b plays a role for decreased IGF-1 that induces insulin resistance in human hepatocellular carcinoma. PLoS One 9: e89446, 2014.

103. Ren J, Chu Y, Ma H, Zhang Y, Zhang X, Zhao D, Li Z, Wang J, Gao YE, Xiao L, et al: Epigenetic interventions increase the radiation sensitivity of cancer cells. Curr Pharm Des 20: 1857-1865, 2014.

104. Zhou S, Ye W, Ren J, Shao Q, Qi Y, Liang J and Zhang M: MicroRNA-381 increases radiosensitivity in esophageal squamous cell carcinoma. Am J Cancer Res 5: 267-277, 2015.

105. Ye C, Sun NX, Ma Y, Zhao Q, Zhang Q, Xu C, Wang SB, Sun SH, Wang F and Li W: MicroRNA-145 contributes to enhancing radiosensitivity of cervical cancer cells. FEBS Lett 589: 702-709, 2015.

106. Li T, Yin J, Yuan L, Wang S, Yang L, Du X and Lu J: Downregulation of microRNA-139 is associated with hepatocellular carcinoma risk and short-term survival. Oncol Rep 31: 1699-1706, 2014.

107. Gu W, Li X and Wang J: miR-139 regulates the proliferation and invasion of hepatocellular carcinoma through the WNT/TCF-4 pathway. Oncol Rep 31: 397-404, 2014.

108. Liang X, Zeng J, Wang L, Fang M, Wang Q, Zhao M, Xu X, Liu $\mathrm{Z}, \mathrm{Li} \mathrm{W}$, Liu S, et al: Histone demethylase retinoblastoma binding protein 2 is overexpressed in hepatocellular carcinoma and negatively regulated by hsa-miR-212. PLoS One 8: e69784, 2013.

109. Ma Y, She XG, Ming YZ and Wan QQ: miR-24 promotes the proliferation and invasion of HCC cells by targeting SOX7. Tumour Biol 35: 10731-10736, 2014.

110. Dai W, Wang C, Wang F, Wang Y, Shen M, Chen K, Cheng P, Zhang Y, Yang J, Zhu R, et al: Anti-miR-197 inhibits migration in HCC cells by targeting KAI 1/CD82. Biochem Biophys Res Commun 446: 541-548, 2014.

111. Yang YF, Wang F, Xiao JJ, Song Y, Zhao YY, Cao Y, Bei YH and Yang CQ: MiR-222 overexpression promotes proliferation of human hepatocellular carcinoma HepG2 cells by downregulating p27. Int J Clin Exp Med 7: 893-902, 2014.

112. Pang F, Zha R, Zhao Y, Wang Q, Chen D, Zhang Z, Chen T, Yao M, Gu J and He X: MiR-525-3p enhances the migration and invasion of liver cancer cells by downregulating ZNF395. PLoS One 9: e90867, 2014.

113. Sun Z, Meng C, Wang S, Zhou N, Guan M, Bai C, Lu S, Han Q and Zhao RC: MicroRNA-1246 enhances migration and invasion through CADM1 in hepatocellular carcinoma. BMC Cancer 14: 616, 2014.

114. Köberle V, Kronenberger B, Pleli T, Trojan J, Imelmann E, Peveling-Oberhag J, Welker MW, Elhendawy M, Zeuzem S, Piiper A, et al: Serum microRNA-1 and microRNA-122 are prognostic markers in patients with hepatocellular carcinoma. Eur J Cancer 49: 3442-3449, 2013. 
115. Ge W, Yu DC, Li QG, Chen X, Zhang CY and Ding YT: Expression of serum miR-16, let-7f, and miR-21 in patients with hepatocellular carcinoma and their clinical significances. Clin Lab 60: 427-434, 2014

116. Meng FL, Wang W and Jia WD: Diagnostic and prognostic significance of serum miR-24-3p in HBV-related hepatocellular carcinoma. Med Oncol 31: 177, 2014.

117. Luo J, Chen M, Huang H, Yuan T, Zhang M, Zhang $\mathrm{K}$ and Deng S: Circulating microRNA-122a as a diagnostic marker for hepatocellular carcinoma. Onco Targets Ther 6: 577-583, 2013.

118. Zhang ZQ, Meng H, Wang N, Liang LN, Liu LN, Lu SM and Luan Y: Serum microRNA 143 and microRNA 215 as potential biomarkers for the diagnosis of chronic hepatitis and hepatocellular carcinoma. Diagn Pathol 9: 135, 2014.
119. Li J, Wang Y, Yu W, Chen J and Luo J: Expression of serum miR-221 in human hepatocellular carcinoma and its prognostic significance. Biochem Biophys Res Commun 406 : 70-73, 2011.

120. Zhan MX, Li Y, Hu BS, Shao PJ, Meng QW, He X, Huang JW and Lu LG: Expression of serum microRNAs (miR-222, miR-181, miR-216) in human hepatocellular carcinoma and its clinical significance. Zhonghua Yi Xue Za Zhi 93: 1830-1832, 2013 (In Chinese). 